\title{
Investigating Heavy Metal Pollution of a Residential Area in Nsukka, Enugu State of Nigeria and Associated Risks
}

\author{
Author: Uzochukwu Cornelius Ugochukwu \\ SHELL/UNN Centre for Environmental Management and Control, \\ University of Nigeria, Enugu Campus, Enugu, Nigeria
}

\begin{abstract}
The soils of residential areas close to high traffic roads are susceptible to heavy metal contamination as a result of urban or sub-urban activities. In this study, the heavy metal contamination of a soil area in Nsukka of Enugu state was investigated with a view to ascertaining the geochemical baseline and hitherto contamination. The heavy metals determined were $\mathrm{Cu}, \mathrm{Pb}, \mathrm{Zn}, \mathrm{Cr}$ and $\mathrm{Cd}$ which were measured by means of Atomic Absorption Spectrometry. The extent of pollution of the soil environment was evaluated using, contamination factor (CF), geochemical accumulation index $\mathrm{I}_{\text {geo }}$, and pollution load index (PLI) whereas the ecological risks was evaluated using potential ecological risk index (PERI). Obtained results show that the mean concentration values of the heavy metals were $18.5,23.4,57.5,78.2$ and $3.1 \mathrm{mg} / \mathrm{Kg}$ for $\mathrm{Pb}, \mathrm{Cu}, \mathrm{Cr}, \mathrm{Zn} \mathrm{Cd}$ respectively. The soil is contaminated with $\mathrm{Cd}$ as $\mathrm{CF}$ and $\mathrm{I}_{\text {geo }}$ are both higher than unity. However, the PLI of 0.33 for the entire soil area indicates insignificant pollution. The PERI value of 98.4 which is less than 110 also indicates insignificant ecological risks. The soil area therefore can be used for the intended project of rearing household animals but the Cd level would need to be constantly monitored.
\end{abstract}

Keywords: Heavy metals, Soil, Pollution, Contamination indices

DOI: $10.7176 / \mathrm{JEES} / 9-1-08$

\section{INTRODUCTION}

Heavy metal contamination of the environment can occur via anthropogenic or/ and natural activities and could lead to exposure risks by humans and animals especially household animals. Animals are usually exposed to the heavy metals in soils as they pick their food from the soil and children who inadvertently ingest soil while playing are also exposed. Furthermore, heavy metals in soils which are mobilized through several physico-biochemical processes could enter the food chain where in addition to being harmful to the biota are deleterious to humans (Godt et al., 2006; Ettler, 2015). The common natural activities that could lead to the release of heavy metals in the environment include weathering of rocks which depending on the geological content of the rock will release metals of different types (Alloway, 1990; Kabata-Pendias and Pendias, 2001). The weathering of rocks as a major influence on soil heavy metal composition can actually account for contamination stances (Salonen and Korkka-Niemi, 2007).

Heavy metal background level and geochemical baseline level are two loosely related but distinct ways of establishing the concentration of heavy metals in a given location. The background level refers to the concentration of the heavy metals absolutely due to natural activities without any input from anthropogenic activities whereas geochemical baseline refers to both the background level and inputs due to human activities that are already in existence (Matschullat et al., 2000; Garcia-Sanchez et al., 2010, Cicchella et al., 2005; Albanese et al., 2007). The origin of heavy metals found in soil due to human activities includes aerial deposition of particles released from different activities such as mining and vehicular emissions (Woszczyk et al., 2018; Pacyna and Pacyna, 2001). It is extremely herculean if not an impossible task to determine the natural heavy metal levels of virgin soils as there would always be contamination from atmospheric deposition making it impossible and infact unnecessary to use background levels for environmental assessment (Chen et al., 1999; Wei and Wen, 2012). Consequently, geochemical baseline level is the preferred means of environmental assessment. Information from geochemical baseline assessment would make it possible to carry out environmental risk assessment and guide policy formulation and implementation (Baize and Sterckeman, 2004). This is derived from the utilization of geochemical baseline data in the determination of pollution indices such as contamination factor, pollution load index and geo-accumulation index. It is equally handy in determining potential ecological risk index.

Several studies have reported the contamination level of soils and associated risks in both residential and industrial areas from several regions of the world (Chen et al., 1999; Pacyna and Pacyna, 2001; Santos-Frances et al., 2017; Woszczyk et al., 2018). However, studies on the geochemical baseline levels of heavy metals and the associated risks are not common in Nigeria. There are several anthropogenic activities in Nigeria such as vehicular and mining emissions capable of elevating background levels. The motivation for this study is derived from an impending farm project in the study area involving poultry and other livestock for which environmental risks would need to be established. The soils of the study area are suspected to have been affected by anthropogenic input of heavy metals from vehicular emissions and therefore would require to be assessed to be 
able to establish geochemical baseline levels. The objectives of the study therefore are:

- $\quad$ Establish the geochemical baseline concentration of the select heavy metals $(\mathrm{Cu}, \mathrm{Zn}, \mathrm{Pb}, \mathrm{Cr}$ and $\mathrm{Cd})$ in the soil of the study area

- Estimate extent of pollution using pollution indices

- $\quad$ Estimate ecological risks using potential ecological risk index (PERI).

\section{MATERIALS AND METHODS}

\subsection{Study Location}

The study area is located in Nsukka LGA which lies between longitudes $7^{0} 13^{\prime} 00^{\prime}$ ' - 7 $7^{0} 35^{\prime} 30^{\prime}$ ' and latitudes $6^{0} 43^{\prime} 30^{\prime \prime}-7^{0} 00^{\prime} 30^{\prime}$ ' in Enugu State, Southeastern Nigeria covering a total land area of approximately 480 square kilometer. The geo-reference of the study area is: $\mathrm{N} 06^{0} 50^{\prime} 30.7^{\prime \prime}$, and E00 $7^{0} 23$ ' 34.7', The entire Nsukka including the study area is underlain by the following geological formations, Mamu Formation, Ajali Formation and Nsukka Formation. The Mamu Formation consist of fine to medium grained, white to grey sandstones, shaly sandstones, sandy shales, grey mudstones, shales and coals. The Ajali Formation, also known as False Bedded Sandstone, consists of thick friable, poorly sorted sandstones, typically white in colour but sometimes iron stained. The Nsukka Formation lies conformably on the Ajali sandstone. Unconfined aquifer units in the study area occur mostly in the Ajali Sandstone, and represent sections of the formation where the semi-permeable or impermeable cap beds have either been eroded or absent. Perched aquifer conditions occur mostly in the lateritic/red earth cover over the Nsukka Formation and in the upper sandy units of the Nsukka Formation. The perched aquifer is generally thin and measurements in dug holes gave thickness values ranging from $3 \mathrm{~m}$ to $8 \mathrm{~m}$ with an average of about $4.6 \mathrm{~m}$ (Uma, 2003). The map of Enugu State showing Nsukka LGA where the study area is located is as given in Figure 1.

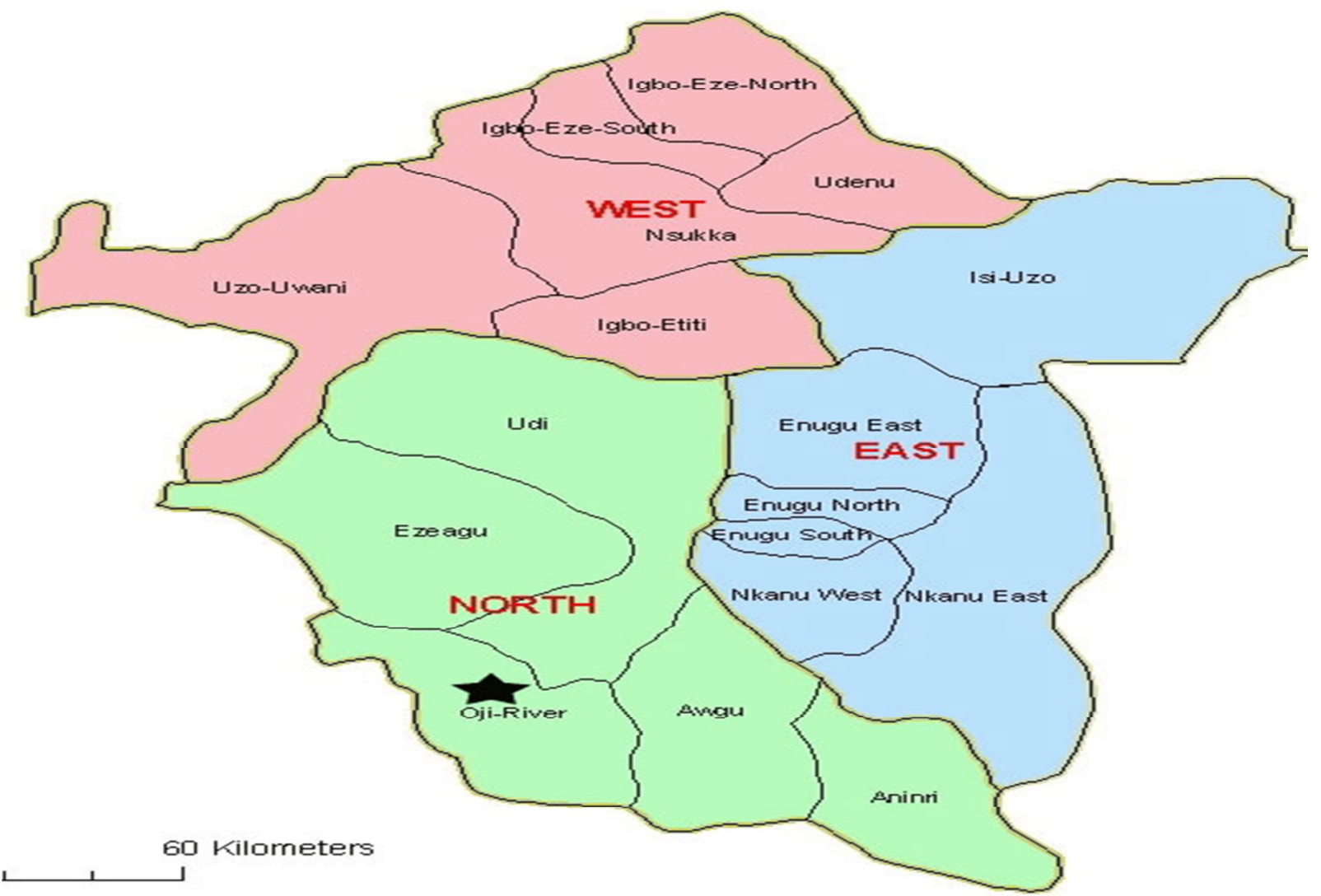

Figure 1 Map of Enugu State showing Nsukka LGA where study site is located.

Source: https://www.google.com/search?q=map+of+enugu+state

\subsection{Sampling}

10 samples were randomly collected in a $2500 \mathrm{~m}^{2}$ land area in the month of February 2018 . The top soil $(0-10$ $\mathrm{cm})$ samples were collected into a black polythene bag and sealed. The soil samples were put into a sampling box filled with ice cubes for maintaining sample temperature below $4{ }^{0} \mathrm{C}$ and transported to the laboratory for analysis. 


\subsection{Laboratory analysis of soil samples}

The soil samples were air dried and passed through a $2 \mathrm{~mm}$ mesh sieve to remove plant debris and stones. The sieved sediment samples were ground to powder using pestle and mortar and passed through a $3 \mathrm{~mm}$ mesh sieve to collect fine soil samples. The soil samples were acid digested and filtered using $0.45 \mu \mathrm{m}$ filter membrane. Additional water was added to make up the volume to $50 \mathrm{~mL}$ and stored in the refrigerator below $4{ }^{0} \mathrm{C}$ until required for analysis. The heavy metals $(\mathrm{Cu}, \mathrm{Zn}, \mathrm{Cr}, \mathrm{Pb}, \mathrm{Cd})$ were analyzed using SensAA GBC Flame Atomic absorption.

\subsection{Pollution Assessment and Ecological Risks Due to Heavy Metals in the soil}

Ecological assessment of the sediments polluted by heavy metals was carried out by means of contamination factor $(\mathrm{CF})$, geo-accumulation index $\left(\mathrm{I}_{\text {geo }}\right)$, pollution load index (PLI) and potential ecological risk index (PERI).

\subsubsection{Contamination factor}

Contamination factor (CF) was determined as proposed by Hakanson (1980).

$\mathrm{CF}=\mathrm{C}_{\text {sediment }} / \mathrm{C}_{\text {background }}$ Eq. 1

Where:

$\mathrm{C}_{\text {sediment }}=$ heavy metal mean concentration in the soil

$\mathrm{C}_{\text {background }}=$ heavy metal concentration in the background

The background values used were those reported by Hakanson (1980).

\subsubsection{Geo-accumulation index $\left(\mathrm{I}_{\text {geo }}\right)$}

The geo-accumulation index $\left(\mathrm{I}_{\mathrm{geo}}\right)$ is determined as follows:

$\mathrm{I}_{\mathrm{geo}}=\log _{2}\left(\mathrm{C}_{\mathrm{n}} / 1.5 \mathrm{~B}_{\mathrm{n}}\right)$ Eq. 2

Where:

$\mathrm{C}_{\mathrm{n}}=$ concentration of heavy metals in the soil

$\mathrm{B}_{\mathrm{n}}=$ geochemical background value

1.5 is matrix correction factor that minimizes lithogenic effects (Yi et al., 2016).

2.4.3 Pollution load index (PLI)

Pollution load index (PLI) measures the extent of pollution of the soil and is expressed as proposed by Tomlinson et al. (1980):

$\mathrm{PLI}=\left(\mathrm{CF}_{1} * \mathrm{CF}_{2} * \mathrm{CF}_{3} *\right.$ . $\left.\mathrm{CF}_{\mathrm{n}}\right)^{1 / \mathrm{n}}$ -Eq. 3

Where:

$\mathrm{CF}=$ contamination factor

$\mathrm{n}=$ number of heavy metals in the sediment sample

\subsubsection{Potential ecological risk index (PERI)}

PERI of the heavy metals in the sediments which is derived from summing the potential ecological risk factor (PERF) of the individual heavy metals is given as described in equation 4.

$\mathrm{PERF}=\mathrm{CF}^{*} \mathrm{TRC}$ -Eq. 4

Where:

$\mathrm{CF}=$ contamination factor

$\mathrm{TRC}=$ toxic response coefficient for a given heavy metal. This study adopted the TRC reported in Hakanson (1980). TRC is a measure of the toxicity and ecological sensitivity of the heavy metals.

$\mathrm{PERI}=\mathrm{PERF}_{1}+\mathrm{PARF}_{2}+\mathrm{PERF}_{3}+\ldots \ldots \ldots . . . \mathrm{PERF}_{\mathrm{n}}$ Eq. 5

\section{RESULTS AND DISCUSSIONS}

3. 1 Concentration of the heavy metals

The concentration of the heavy metals in the study area is as shown in Table 1.

Table 1 Concentration of the heavy metals

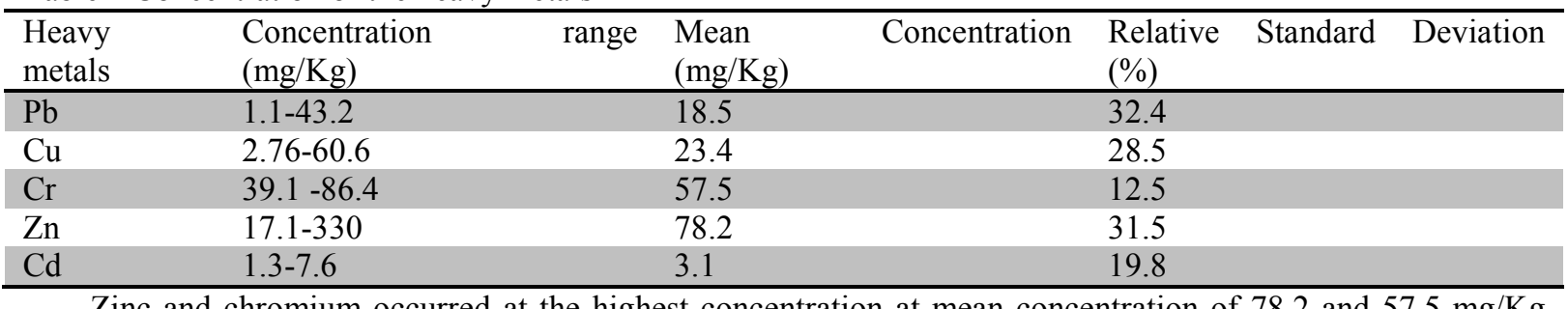

Zinc and chromium occurred at the highest concentration at mean concentration of 78.2 and $57.5 \mathrm{mg} / \mathrm{Kg}$ (Table 1). Studies carried out in another part of the country show higher values of these heavy metals (Olajire et al., 2003). In comparison with studies carried out in other parts of the world such as Peru, the concentration values reported in this study are higher except for cadmium and lead (Santos-Frances et al., 2017). However, in another research carried out in Kazakhstan where only cadmium, copper, lead and zinc were studied, all the concentration values for all the studied sites are higher than those of this study (Woszczyk et al., 2018). Sub- 
urban pollution which include indiscriminate disposal of waste and emissions are generally regarded as the major source of anthropogenic release of heavy metals into soil environment and is possibly the source of heavy metals in the study area.

\subsection{Assessment of Environmental Pollution}

The assessment of the environmental pollution of the study area based on pollution assessment indices such as contamination factor $(\mathrm{CF})$, geochemical-accumulation index $\left(\mathrm{I}_{\text {geo }}\right)$, pollution load index (PLI) and potential ecological risk index (PERI) is as presented in Table 2.

Table 2 Environmental Pollution Assessment Indices

\begin{tabular}{lllll}
\hline Heavy metals & $\mathrm{CF}$ & $\mathrm{I}_{\text {geo }}$ & PLI & PERF \\
\hline $\mathrm{Pb}$ & 0.26 & -2.5 & 0.33 & 1.3 \\
$\mathrm{Cu}$ & 0.46 & -1.69 & & 2.3 \\
$\mathrm{Cr}$ & 0.63 & -1.24 & & 1.26 \\
$\mathrm{Zn}$ & 0.44 & -1.75 & & 0.44 \\
$\mathrm{Cd}$ & 3.1 & 1.05 & & 93 \\
$\mathrm{PERI}$ & & & 98.4 \\
\hline PERF & & & &
\end{tabular}

PERF $=$ Potential ecological risk factor

The contamination factor for all the heavy metals other than cadmium is less than unity indicating that these heavy metals are not occurring at concentration levels capable of contaminating the study area. Unlike cadmium with contamination factor above unity indicating likely contamination with cadmium, these other heavy metals are below the naturally expected background levels. The geochemical accumulation index $\left(\mathrm{I}_{\text {geo }}\right)$ for $\mathrm{Pb}, \mathrm{Cu}, \mathrm{Zn}$ and $\mathrm{Cr}$ are all less than zero (Table 2) indicating that the soil is uncontaminated with these heavy metals. However, the $I_{\text {geo }}$ value of more than unity but less than 2 for $\mathrm{Cd}$ indicates that the soil is moderately contaminated (Woszczyk et al., 2018). In comparison with other studies carried out in Nigeria, the study site is not as polluted (Olajire et al., 2003). Similarly, in comparison with studies carried out in other parts of the world such as Iran and China, the study site is also not as polluted. Example, in the studies carried out in Iran, PLI value of 8 was reported and in China, it was as high as 13 (Qishlaqi and Moore, 2007; Yuan et al., 2017).

The PERI of 98.4 (Table 2) which is less than 110 indicates low ecological risk demonstrating that the study site may not pose any significant risks to household animals in the study area and therefore deemed suitable for the intended poultry and household animal rearing venture.

\section{CONCLUSION}

The study arae, having been investigated for heavy metal contamination has been found to be uncontaminated with heavy metals such as $\mathrm{Zn}, \mathrm{Pb}, \mathrm{Cu}$, and $\mathrm{Cr}$ but contaminated with $\mathrm{Cd}$ as inferred from pollution indices such as contamination factor and geochemical accumulation index. Though contaminated with cadmium, the level of contamination is ranked moderate. The pollution load index indicates that the study area is not polluted. The evaluation of ecological risk using potential ecological risk index indicates low risks demonstrating that the study area may not pose any significant health risks to household animals including poultry. This study having established low ecological risks of the study area with respect to heavy metals, do recommend the study area for carrying out poultry and animal husbandry business. However, levels of cadmium should be monitored.

\section{AKNOWLEDGEMENT}

The support of SHELL/UNN Centre for Environmental Management \& control throughout this study is highly appreciated.

\section{REFERENCES}

Albanese, S., De-Vivo, B., Lima, A., Cicchella, D. 2007. Geochemical background and baseline values of toxic elements in stream sediments of Campania region (Italy). Journal of Geochemistry and Exploration, 93, 2134.

Alloway, B.J. 1990. Heavy metals in soils. Blackie Academic \& Professional, London, UK.

Baize, D., Sterckeman, T. 2004. On the necessity of knowledge of the natural pedo-geochemical background content in the evaluation of the contamination of soils by trace elements. Science of The Total Environment, 264, 127-139.

Chen, M., Ma, L.Q., Harris, W.G. 1999. Baseline concentrations of 15 trace elements in Florida surface soils. Journal of Environmental Quality, 25, 1173-1181

Cicchella, D., De Vivo, B., Lima, A. 2005. Background and baseline concentration values of elements harmful to human health in the volcanic soils of the metropolitan provincial area of Napoli (Italy). Geochemical Exploration and Environmental Analysis, 5, 29-40.

Ettler, V. 2015. Soil contamination near non-ferrous metal smelters: a review. Applied Geochemistry, 64, 56-74. 
Garcia Sanchez, A., Alonso Rojo, P., Santos Frances, F. 2010. Distribution and mobility of arsenic in soils of a mining area (Western Spain). Science of The Total Environment, 408, 4194-4201.

Godt, J., Scheidig, F., Grosse-Siestrup, C., Esche, V., Brandenhung, P., Reich, A., Groneberg, D.A. 2006. The toxicity of cadmium and resulting hazards for human health. Journal of Occupational Medicine \& Toxicology. DOI: 10.1186/1745-6673-1-22.

Hakanson, L. 1980. An ecological risk index for aquatic pollution control of sediments: ecological approach. Water research, 14, 975-1000.

Kabata-Pendias, A., Pendias, H. 2001. Trace elements in soils and plants, CRC Press Inc.: Boca Raton, FL, USA.

Matschullat, J., Ottenstein, R., Reimann, C. 2000. Geochemical background-Can we calculate it? Environmental Geology, 39, 990-1000.

Olajire, A.A., Ayodele, E.T., Oyedindan, G.O., Oluyemi, E.A. 2003. Levels and speciation of heavy metals in soils of Industrial Southern Nigeria. Environmental Monitoring and Assessment, 85, 135-155.

Pacyna, J.M., Pacyna, E.G. 2001. An assessment of global and regional emissions of trace metals in the atmosphere from anthropogenic sources worldwide. Environmental Reviews, 9, 269-298.

Qishlaqi, A., and Moore, F. 2017. Statistical analysis of accumulation and sources of heavy metals occurrence in agricultural soils of Khoshk River banks, Shiraz. Iranian Environmental Science, 2, 565-573.

Salonen, V., Korkka-Niemi, K. 2007. Influence of parent sediments on the concentration of heavy metals in urban and suburban soils in Turku, Finland. Applied Geochemistry, 22, 906-918.

Santos-Frances, F., Martinez-Grana, A., Rojo, P.A., Sanchez, A.G. 2017. Geochemical background and baseline values determination and spatial distribution of heavy metal pollution in soils of the Andes Mountain Range (Cajamarca-Huancavelica, Peru). International Journal of Environmental Research and Public Health, 14, 859-880.

Tomlinson, D.L., Wilson, J.G., Harris, C.R., Jeffrey, D.W. 1980. Problems in the assessment of heavy-metal levels in estuaries and the formation of a pollution index.Helgolander Meeresunters, 33, 566-575.

Ugochukwu, U.C., Ochonogor, A., Jidere, C.M., Agu, C., Nkoloagu, F., Ewoh, J., Okwu-Delunzu, V.U. 2018. Exposure risks to polycyclic aromatic hydrocarbons by humans and livestock (cattle) due to hydrocarbon spill from petroleum products in Niger-delta wetland. Environment International, 115, 38-47.

Uma KO (2003). Hydrogeology of the perched aquifer systems in the hilly terrains of Nsukka town, Enugu State, Nigeria. Water

Resources J. NAH, 14: 85 - 92.

Wei, C., Wen, H. 2012. Geochemical baselines of heavy metals in the sediments of two large freshwater lakes in China: Implications for contamination character and history. Environmental Geochemistry and Health, 34, 737-748

Woszczyk, M., Spychalski, W., Boluspaeva, L. 2018. Trace metal (Cd, Cu, Pb, Zn) fractionation in urbanindustrial soils of Ust-Kamenogorsk (Oskemen), Kazakhstan-implications for assessment of environmental quality. Environmental Monitoring and Assessment, 190, 362-377.

Yuan, Y., Xiang, M., Liu, C., Theng, B.K.G. 2017. Geochemical characteristics of heavy metal contamination induced by a sudden wastewater discharge from a smelter. Journal of Geochemical Exploration, 176, 33-41. 